\title{
Evaluating the Nature and Extent of Burglary at Residential Premises in Namakgale Policing Area, South Africa
}

\author{
M. Mundlovu, D. Khosa* and E. Zenzile
}

\author{
Tshwane University of Technology, Aubrey Matlala Street, Soshanguve, Pretoria, South Africa
}

\begin{abstract}
The main objective of this paper was to explore the nature and extent of burglary at residential grounds in the Namakgale policing area, after realisation of higher manifestations and uncontrollable nature of this crime. This paper utilised a qualitative research approach, supported by the phenomenological research design. Altogether, 30 participants were purposively selected from diverse target groups, which consists of the South African Police Service Detectives, uniform police officers, Community Policing Forum (CPF) members and managers, Community Leaders and Faith-based organisation leaders, and local community members. The objectives of the paper were realised by the use of one-on-one semi-structured interviews for data collection, and thematic analysis, in order to analyse the gathered data.

Research findings of this paper revealed that the current strategies of traditional policing, such as a) foot patrolling offered by the selected stakeholders, and $b$ ) the vehicle patrolling rendered by the local SAPS members, are deemed to be ineffective. There is an increase in the number of burglaries at residential premises at Namakgale policing area, and the reported cases tend to be often unsolved. There are constant complaints made by community members about burglary in their premises. It is also established that security systems can play an essential role in deterring the commission of this crime and the failing trust within the community members and the local SAPS should be rebuilding.

This empirical research paper recommends that Namakgale community, local SAPS and other relevant stakeholders should clearly understand the Modus Operandi (MO) used in the commission of this ordeal crime. The understanding of the $\mathrm{MO}$ would serve as a detail-rich information and subsequently influence strategies, on how to effectively respond to this crime.
\end{abstract}

Keywords: Burglary at residential premises, Combating, Exploration, Investigations, Namakgale policing area, Prevention, Responses, SAPS.

\section{INTRODUCTION, BACKGROUND AND PROBLEM FORMULATION}

Burglary at different residential grounds, which is also referred to as "housebreaking", is a crime committed by an individual who intentionally and unlawfully breaks into a building or same structure, utilised for human habitation having intentions to execute an offence on the premises, (Institute of Security Studies [ISS] (2018). The criminals intrude into the homes of supposedly innocent individuals and damage the feelings of individual security, wellbeing, and peace of mind further leaving a negative impact on 'victims' thereof (Sonne, 2006). In 2017/18, there were 228,094 house burglaries recorded in South Africa, which can be interpreted into an average of 625 houses per day.

However, approximately, $52.8 \%$ of households did not account for the crime as they thought that the police could not do anything about it. Again, in 2019/20 there were 205,959 house burglaries reported to the police, which is a decrease in the phenomenon in question (Africa Check, 2019) and (Africa Check,

*Address correspondence to this author at the Tshwane University of Technology, Aubrey Matlala Street, Soshanguve, Pretoria, South Africa; Tel: +2712 382 9811; E-mail: khosad@tut.ac.za
2020). According to Stuart Clarkson, the Managing Executive Fidelity ADT [2018] (in Zinn, 2018), there is a very real threat of becoming careless about personal security, despite it being a continued issue for many South Africans. This seminal researcher further revealed this statement verbatim:

"We hear of incidents, we know of people who have been affected and it seems to be a part of normal life for South Africans. But we need to be aware that personal safety should be top of mind always. We cannot become complacent because criminals are opportunistic ... it is interesting to note that reaction officers patrolling suburbs often find gates and garage doors left open ... And often, when there has been a break-in incident at a house, we will find that the alarm was not on at the time. So, while residents have security measures in place they become complacent about their security and do not use them properly ... However, the mind of a criminal is no longer a mystery."

However, with this submission, it is postulated that property crimes will continue to remain a serious social problem. As long as various social-economic factors 
(Unemployment, poor living conditions, lack of material resources and financial needs, among others) are not addressed across the Namakgale policing area, and in South Africa as a whole, crime will remain a social problem. It is also noted that victims of this crime are more likely to experience it over again. The burglar might try their luck again after a while. Van Zyl (2006) stresses that not only does burglary at residential premises intrude on the victim's space, but deprives them of their valuable property. In the same vein, Sonne (2006) attests that burglary at residential premises could still be considered as the most essential crime and the most common form of criminal behaviour in our postmodern society.

Govender (2018) further opines that after the arrival of democracy in 1994, the capability to police this crime in South Africa has become very more challenging and complex, hence the call for innovative and effective police service. The supposition is that the police are not adequately trained to deal with this crime effectively in our democratic regime. The situation of police training can be largely attributed to the background of the previous apartheid-trained liberation movement and police officers cadres with military training who were amalgamated into the police service to conduct policing in a newborn democracy.

Aantjes (2012) went on to emphasise that this serious crime is encompassing financial, psychological and emotional impacts. Dinisman and Moroz (2017) confirm that existing evidence on the main effects of this crime and associated victims' need rest on the following impacts; emotional, psychological, physical, financial and indirect factors. Again, the paper conducted in Germany on this subject confirms that more focus has been placed on the psychological damage of victims. The major results of this paper depict that victims of burglary often experience different anxieties after the offence. It was also revealed that even though most researches were carried out a short time after the burglary, fewer studies have emphasised long-term damage and change in behaviour.

Furthermore, very little is regarded regarding the role and perception of the police related to the interaction with victims (Wollinger, Dreißigacker \& Baier, 2017). Nunlall, Maluleke and Breetzke (2020) point out that an offender usually decides on a particular target and this decision is dependent on the environment and the absence of a potential guardian, for example, security. Also, the frequency of burglary at residential premises depends on the offender's social networks, peer influences, monetary need and likelihood of the crime succeeding. It is also postulated that the choice to continue with certain criminality also depends on internal factors, for example; detections, targets, the age of the criminal and external factors, such as the marital status, carrying an injury or employment status (Andresen, 2014).

From a theoretical perspective, the commission of burglary at the Namakgale policing area can be better explained through the Rational Choice Theory (RCT) developed by Ronald Clarke and Derek Cornish. These two scholars recognised the influence that the environment has on the offender's choice. The RCT assumes that crimes are purposive and deliberate acts, committed benefiting the offender (Cornish \& Clarke, 2008). It proposes that if given an opportunity, or appropriate chance, any person might commit an offence (Felson \& Clarke, 1998). This theory emphasises the motivation of the offender in costbenefit terms and explains how and why crime occurs. The RCT assumed that the offender decides to commit this crime if the benefit (Reward) outweighs the cost (Punishment). The theory suggests that a potential offender has four primary choices to consider: Whether to commit the crime or not, whether to select a particular target or not, how frequently to offend, and whether to continue or discontinue from committing a crime (Andresen, 2014). This is linked with the indicated statistics and discussions provided in Table 1 of this paper. This is based on the fact that there are higher numbers of reported cases, as compared to other property-related crimes in the research location.

This paper provides that the local SAPS is more focused on law enforcement as compared to crime protection and prevention of personal properties. With the restricted resources and personnel at their disposal, the SAPS find it hard to satisfy the expectations and needs of the communities. For example, protection against unarmed and armed burglars and therefore, this paper largely focused on the exploration of SAPS responses to the burglary at residential premises at Namakgale policing area.

\section{Problem Statement}

SAPS in the Namakgale policing area comprises the following locations: Namakgale Zone B, C and E, Majeje Zone $A$ and $B$, as well as, Mashishimale and Makhushane. These identified areas suffer a staggering defeat of policing burglary at residential premises. For analysis; Table 1 depicts the instability 
Table 1: Burglary at Residential Premises

\begin{tabular}{|c|c|c|c|c|c|c|c|c|c|}
\hline Precinct & $\mathbf{2 0 1 2}$ & $\mathbf{2 0 1 3}$ & $\mathbf{2 0 1 4}$ & $\mathbf{2 0 1 5}$ & $\mathbf{2 0 1 6}$ & $\mathbf{2 0 1 7}$ & $\mathbf{2 0 1 8}$ & $\mathbf{2 0 1 9}$ & $\mathbf{2 0 2 0}$ \\
\hline \hline Namakgale & 280 & 330 & 408 & 403 & 379 & 343 & 347 & 431 & 401 \\
\hline
\end{tabular}

Source: SAPS Crime Statistics (2012-2020).

and fluctuation of burglary at residential premises for the past nine (9) financial years (2012-2020). The extent and occurrence of this crime portray unstably, however, it remains increasing. The researchers confirm that this policing area does not have enough manpower to effectively respond to it with ease. The indicated statistics showed this crime is high in the Namakgale policing area. The analysis of these statistics from the paper location provides an understanding of the nature and extent of this crime. Using these statistics, this crime can be easily identified to offer strategies, plans and policies are developed to prevent, investigate combat this crime properly in this study area. As the associated criminal behaviour and characteristics and motives for committing this crime can be shared and managed.

This paper further provides that almost Five per cent $(5 \%)$ of burglars in the Namakgale policing area stand chances of getting caught and sentenced. Altogether, it can also be concluded that the responsible SAPS General Detectives are not adequately trained to deal with this type of crime and they are expected to increase the contest of restraints on police resources by enhancing different innovative and partnership solutions with different stakeholders around the area. They must also try to collect, and distribute good practices on the deterrence and disruption of the burglary at residential premises syndicates across this area. For the success of such interventions, there is a plethora of literature on burglary at residential premises that could be utilised for reshaping and developing effective prevention strategies in the selected research area. Internationally and nationally, debates about this scourge exist.
However, there is limited literature on the nature and extent of the prevalence of this crime in the Namakgale policing area. Additionally, with an increased understanding of this crime, SAPS management and other relevant stakeholders need to devise effective strategies (Mokwena \& Maluleke, 2020, and Mokwena, Motsepe, Maluleke \& Shandu, 2020).

\section{METHODS AND MATERIALS}

This qualitative paper adopted non-probability: Purposive sampling to select 30 participants, consisting of the indicted individuals, as distributed herewith:

All the chosen respondents were subjected to oneon-one semi-structured interviews emanating from Table 2; the indicated selected participants were drawn from the entire population and involved the researchers' decisions about which individuals were suitable for this paper. This sample was regarded to be representative. The aim was to select a sample of participants, which were going to be representative of the entire population, which the researchers aimed to conclude from. Moreover; non-probability: Purposive sampling was adopted to select participants to yield rich information about the topic under research. The burglary at residential premises is a unique study field. Therefore, this sampling was deemed suitable as a few individuals with rich information on this subject had to be selected to provide data on their unique experiences to give direction to this paper (Maluleke, 2014).

To this course; the researchers purposefully selected the sample for this paper based on her knowledge of the entire population, its elements, and

Table 2: Selected Participants

\begin{tabular}{|c|c|}
\hline Selected participants & Selected numbers \\
\hline \hline SAPS detectives & 10 \\
\hline SAPS uniform police officials & 8 \\
\hline CPF members and managers & 5 \\
\hline The community leaders' and Faith-based organisation leaders & 2 \\
\hline The local community members & 5 \\
\hline
\end{tabular}

Source: Researchers emphasis (2019-2020). 
the nature of the paper objectives and directly mapped research questions. For this reason, a total of 30 participants were selected as indicated in Table 2 of this paper. Participants who were deemed experienced in understanding the commission of this crime were selected based on their respective experiences and knowledge on this subject. The selected sample had encountered this crime on numerous occasions, and they were, therefore, all well aware of the latest trends and the various MOs of this crime in the Namakgale policing area. The sample selected provided rich, thick and robust information that answered the aim and objectives of this paper (Maluleke, 2016).

The SAPS detectives, uniform police officials, CPF members and managers, the community leaders' and Faith-based organisation leaders, as well as the local community members, participated in this paper as experts on this subject, they were all knowledgeable about this subject. They possessed rich information as some of them dealt with this crime at the first hand, while others have experienced it. From this qualitative research; the researchers were entitled to select only a few participants to shed the best light on this specific subject. The collected data were analysed by synthesising both primary and secondary sources, the reviewed literature studies and recorded interviews and then integrated it to form coherent information by transcribing it manually.

The original transcripts were broken up and classified all the solicited fragments into various categories. This was done by looking for themes and patterns within the data itself guided by the paper objectives and directly mapped research questions to ease the categorising process, labelling to ease retrieval and management thereof. These labels included descriptions of the paper about the conducted one-on-one semi-structured interviews and consulted literature studies (Maluleke, 2020).

\section{PRELIMINARY LITERATURE REVIEW}

\section{Understanding the Nature and Extent of a Burglary at Residential Premises}

The researchers observed that there have been many changes since the release of crime statistics by the Police Minister. Since the release of these statistics, more materials, such as the Victims of Crime Survey (VOCS), became accessible. These materials were released from 2011 to 2019 by Statistics South Africa (Stats SA), with the ISS also making comments every year upon the release of overall crime statistics. It is also noted by the researchers that the dark figures of the burglary at residential premises exist, further invalidating the accuracy of available statistics of this crime. The result of this is a comparative dearth of research-based literature available upon the subject. Through the transformation and/or categorisation of crime, stats have evolved over time and by comparison, though burglary at residential premises has received greater attention, the adequate response thereof by the local police as realised. To this end, property crimes such as burglary, theft and fraud were committed for the perpetrator's gain (Lushbaugh \& Weston, 2009). To highlight the extent of property crimes in South Africa, burglary at residential premises were reported to be very high, with an overall increase of $6.8 \%$ (SAPS, 2014).

According to Zinn (2017), burglary at residential premises is a huge offence hitting areas with 240000 burglaries each year in South Africa, most burglaries take place during the day when people are at work. These burglaries are opportunistic. He highlighted the following verbatim in this regard:

"They will usually pick an area and go
from house to house, ringing doorbells or
intercoms to see if anyone is home. They
want to get in and out as quickly as
possible so any noise, like dogs on the
property, would act as a deterrent. Dogs
kept inside are the greatest deterrent."

This prolific researcher went on to distinguish between burglars and robbers by revealing that the latter [robbers], scout a neighbourhood to view how taut the security is. Consequently, when interviewed, 68 per cent of the informants stated that a noticeable patrol or Neighbourhood Watch deter them from going in, so having a good Neighbourhood Watch or practical patrolling by a security provider might be a huge deterrent. About $77 \%$ of robbers interviewed that they had help from a source from the house. The Domestic Watch programs authorise local staff to be more safety aware (Zinn, 2017).

The significance of perimeter security was also highlighted, revealing that robbers had fewer chances to hit a home that had a perimeter beam and alarm as they stated it gave the homeowner additional time to arm them and call their police or security provider. The robbers typically went into houses between 4 Post Meridiem (PM) and 10 PM as people were at home and 
did not have their alarms set (Zinn, 2017). The extent of this crime in South Africa provides that in 2018/19 there were around 260,000 occurrences of home robberies that affected approximately $1 \%$ of all the households. The most probable victims of the home burglary were households in metros, households headed, and white-headed households by youngsters. The common weapons used in the home robbery were guns $(54 \%)$ and knives (47\%). Approximately $60 \%$ of households accounted for more incidences of home robbery to the police. The number of households that reported occurrences of home robbery is around 120,000 (VOCS, 2018/19).

This indicates that the number of SAPS of reported cases of burglary at the residential premises for $2018 / 19$ is outside the $95 \%$ confidence interval for the approximated number of reported cases. This entails that the approximated number of reported cases from the Governance, Public Safety and Justice Survey (GPSJS) is greater than the number of cases of burglary at residential premises reported by SAPS. Moreover, between 2017/18 and 2018/19, burglary at the residential premises accounted to SAPS enhanced in the Northern Cape, KwaZulu-Natal, North West and Limpopo, while it declined in all the other provinces and South Africa (VOCS, 2018/19).

\section{Profiles and Modus Operandi of Burglars at Residential Premises}

This section predominantly views the burglar's profiles. Zinn (2018) outlines that the profiling perpetrators consists of the following as confirmed by 30 interviewed participants:

- $\quad$ All were men, except for two women who were convicted as accessories.

- They represented South Africa's racial demographic profile.

- $\quad 83 \%$ were South African citizens and the others were from other nations of Africa.

- $\quad$ They were aged 19 to 26 .

- On an average basis, they formed a group of four during an attack.

- $\quad$ Only $20 \%$ had finished high school.

- $\quad 76 \%$ were unemployed, but many people from this number had selected to make money solely from burglaries.
- $80 \%$ did not achieve any type of military or security related training and the others were hired as security guards or worked in the police or military.

- $\quad$ All were experienced criminals.

- Each admitted to having committed approximately 103 crimes over seven years before being arrested for the first time.

- $70 \%$ came from what was explained as dysfunctional or broken homes.

- A distinctive characteristic was the readiness to utilise deadly violence against victims.

Furthermore, other available profiles of burglars relate to the following:

\section{The Amateur Burglars}

The amateur burglar comprises a burglar who commits an offence mainly to save money for drugs. The general profile of the archetypal burglar can be showed as follows like male, young, and underprivileged. To commit this offence, these criminals choose their targets considering different factors. They normally target houses that are located in areas recognisable to them. They also examine the particular location of the house before choosing their target. The house visibility from other houses and roads is also an indicator where the burglars are likely to weigh the probable rewards for their actions in the decisions to entrust crime (Wright \& Miller, 2005). The burglars who are beginners normally conduct their acts in an unsophisticated manner while making little planning. They try to rob a variety of merchandise as opportunities arise. Additionally, they tend to be more interested in stealing a huge number of merchandise [items volume] instead of quality; they seldom specialised in theft of particular items. The beginners are the part-time burglars who associate burglary at the residential premises as only a less, episodic part of criminal life in general. They try to commit opportunity burglaries when a proper target happens, while included in other regular activities whether they are unlawful or lawful (Van Zyl, 2006).

\section{The Professional Burglar}

The professional burglars refers to those people who work at a burglary at housing premises as trade and making their living by burglary at the larceny and residential premises alone and possessing no other 
mediums of income. The professional burglars are considered to be older and are the specialists who hire considerable planning and skill in implanting burglary at housing premises and choose targets that are of substantial value, for instance, the robbery of jewellery (Beirne \& Messerschmidt, 1995). In implementing such practices, they learn their trade from other different professional thieves and make themselves informed regarding the latest burglary at the tools of residential premises like saws and drills. The professional burglar often uses tipsters for the recognition of probable burglary at the housing premises targets (Van Zyl, 2006).

\section{Specialist Burglary}

These are the top fight burglars who concentrate on rich estates, select targets properly, and usually work within a crime ring. Only those items that are of high value will suffice, and thus specialist burglars also tend to target warehouses and businesses and they are opportunists. Fischer, Halibozek and Walters (2019) wrote that they look for opportunities often to advocate a drug habit or other uncivil rationales for shifting the stuff into cash.

\section{The Simple Burglar}

Simple burglary at residential premises describes the act of entering any kind of structure without any kind of permission, irrespective of whether or not the entry is locked to steal something inside. This robber tries to seek easy fast targets, like unlocked doors and opened windows. Since the easiness of offence is the driving force instead of superior information of valuables and this burglar ends up with the 'stuff' that can be exchanged for cash (Fischer, Halibozek \& Walters, 2019).

\section{The Aggravated Burglar}

Fischer, Halibozek and Walters (2004) submit that the provoked burglar gains admission to a structure. A criminal gets unapproved entry into a building, this refers to an individual or the intruder has an unsafe weapon or burglar entrusts harm to the person.

\section{Home Invasion Burglar}

In contrast to the aggravated burglary in which the robber does not remember that the structure is occupied during the crime, the invader of the home remembers in advance that at least one person is inside and premeditates to use force or violence against the person. Alternatively, the intention is to deface or damage the interior. Besides, the looter takes benefit of an establishment, vehicle, and dwelling that is unsecure because of the hurricane and another natural disaster, or because of mass rioting (Fischer, Halibozek \& Walters, 2019).

\section{DATA PRESENTATIONS AND DISCUSSIONS}

The following themes were identified in this paper:

\section{Theme 1: The Emergency Response Period}

What emerges from the data is that the emergency response time to complaints of the burglary at the residential premise was unacceptable in the study area. The limited response time by the local SAPS members can be attributed to inadequate resources, such as an insufficient number of police vehicles to assist in the inner city, townships and rural areas of the Namakgale area. As a result, the responding SAPS officials take a long time to respond to the reported emergency calls, which reduces the chances of catching the suspects in action during the commission

Table 3: Verbatim Views on the Emergency Response Period

\begin{tabular}{|c|c|}
\hline Participant 1: & $\begin{array}{c}\text { "Some of the challenges are that you find that the crime scene has been unoccupied for some time ago or the place } \\
\text { has no address and complainant has already left" }\end{array}$ \\
\hline Participant 24: & $\begin{array}{c}\text { "The Namakgale policing area has increased significantly but the manpower and the resources never increased which } \\
\text { makes it difficult for a member to respond quickly" }\end{array}$ \\
\hline Participant 25: & $\begin{array}{c}\text { "Our community members are reluctant to come out with the information. There are negative attitudes displayed by } \\
\text { some of our police when attending to the burglary in residential premises, coupled with a failure to conduct a } \\
\text { preliminary investigation" }\end{array}$ \\
\hline Participant 21: & $\begin{array}{c}\text { "Some of the members who are the first responder to the crime lack adequate skills, subsequently they contaminate the } \\
\text { crime scene, thus it makes it difficult to collect exhibit neither to do a preliminary investigation" }\end{array}$ \\
\hline Participant 24: & "Some of the investigating officers are not doing their job properly due to laziness and some are corrupt" \\
\hline Participant 24: & "The burglars are now alert and vigilant, they leave no trace, are very few burglars that are found and convicted" \\
\hline Participant 25: & "Some of the community works with the burglar, it is difficult for the police to trace the burglars" \\
\hline
\end{tabular}

Source: Researchers emphasis (2019-2020). 
of this crime. Equally, the community members are currently becoming reluctant to report this crime, as they are developing a lack of trust in the police. This is what the selected participants had this to say regarding this matter:

In support of the presented verbatim expressions herewith, the survey conducted by the Stats SA reveals that only 33\% (Percent) of South African households that reported the burglary at residential premises had satisfaction with the police response. Both male and female-headed families had equal satisfaction with the police response to the burglary at residential premises. It was clear that the white population with the highest percentage of $53 \%$ (per cent) of households who reported the burglary at residential premises were satisfied with the police response to housebreaking reporting. The least satisfied were Black African and coloured population groups with $30 \%$ (per cent) being satisfied with the police response. Northern Cape is the highest province that is happy with the police response to the burglary at residential premises (Maluleke, 2018). The local SAPS [Namakgale policing area] visit to the scene is very important looking at how victims view the services provided by the police. The victim satisfaction is dependent on a reasonably quick arrival to the response of burglary.

\section{Theme 2: Response Times to Burglar Alarms}

The local SAPS response times to burglar alarms were recorded as insufficient. There is little evidence according to this paper to show that the local SAPS members are effective in responding to the burglar alarms. The often implemented strategy offered by the police includes preventive patrol to enhance the response time to citizen calls and cater for police omnipresence, to offer follow-up investigations to reduce this crime and work against the existing fears. Other participants reported that they derive no joy when it comes to the offered police responses, this is what pans out:
Minnaar (2004) stresses the fact that responding to burglar alarms was strictly seen as one of the police duties in combating and preventing crime. However, with years passing, the private security duty took over this function. Subsequently, several local police stations are not being linked to the burglar alarm system anymore, instead, the private security systems are the ones who screen security alarms and only forward the positive calls to the police. Coupe and Griffiths (1998) further contend that when everything was in its place, the police responding time to inprogress alerts took less time and they responded only in few minutes.

However, currently, burglars are aware of the time that the police take when they respond to an inprogress burglary at residential premises. This situation becomes favourable to them as it makes it easy for them to take whatever they want at that limited time and escape successfully. The police should be able to respond quickly to burglary. Other factors affect the successful response to the burglary at residential premises found in development. The chances of a burglary at residential premises being reported in development depends upon the socio-demographics and environmental design of the neighbourhood. The fewer burglaries in progress reported in rural areas because only a few houses have access to cell phones or telephones. While others are afraid to take any action against the perpetrator because they may experience other offences from them such as assault or rape especially for women (Coupe \& Griffiths, 1998).

\section{Theme 3: Security in the Identified Premises}

Burglary at residential premises was cited as a crime of opportunity. It was established that burglars often limit their activities relating to this crime to certain areas in Namakgale, further reducing the existing scope of their burglary activities, however, every area has [many] opportunities. This crime is regarded as one of the most significant crimes and ordinary forms of the displayed criminal behaviours in the study areas. It

Table 4: Verbatim Indications on Response Times to Burglar Alarms

\begin{tabular}{|c|c|}
\hline Participant 26: & "Police attend to the burglary at residential premises cases very late after they receive related reports" \\
\hline Participant 19: & "The approach is very much ineffective although residents have been taught not to report crime late" \\
\hline Participant: 23: & "Thus, police are not able to gather enough evidence so that it may be sent for DNA examination" \\
\hline Participant 27: & "The community are not comfortable to give information to the police, as they are also afraid to testify in court" \\
\hline Participant 28: & "Responding time is poor because police have no enough resources to respond faster, there is no enough \\
\end{tabular}

Source: Researchers emphasis (2019-2020). 
Table 5: Verbatim Opinions on Security in the Identified Premises

\begin{tabular}{|c|c|}
\hline Participant 24: & "The challenges commonly observed are that some dwellers neglect their homes in most occasions and some \\
household does not have burglar-proof" & "Unnumbered houses and late reporting of cases" \\
\hline Participant 24: & "Some houses have no numbers displayed in front. Some places like the shacks are not easily found" \\
\hline Participant 25: & "The challenge is when you arrive at the scene of the burglary at residential premises and find a bigger wall which \\
stops the police from attending"
\end{tabular}

Source: Researchers emphasis (2019-2020).

is noted that the burglars intrude into a home of an individual without consent and damage feelings of individual security, the well-being of victims, and peace of mind leaving a negative effect on associated victims and secondary victimisations. Furthermore, what is of specific concern is the capability of some potential criminals to bypass housing safety features like perimeter walls, alarm systems, and guards for the commission of this crime. Other selected participants reported different views on the issue of security at the Namakgale policing area as follows:

The significance of surveillance also suggested that safety prevents accessibility to the plot of housing that might be considered as a more effective option (Weish \& Farrington, 2012). It is observed that a well-defended perimeter must have an urgent impact on a burglary at residential premises when the burglar is making selection targets and any kind of delay in getting access to the residential plot will also increase the opportunities of neighbours or passer-by reporting what was happening. The houses that are standing on large grounds have no chance to be an attractive way of safeguarding a house. Those types of households appear to be the most likely to advantage from using and installing the suggested safety hardware and they are easily accessible to the public area and it is frequently the case with the domestic authority residence.
Such types of households, however, in different cases are likely to have a lower level of income. The major problem for targeting the hardening policies in these kinds of cases is one of influencing householders to fix security. In the case of houses of the local authority, the authority itself might install security hardware although there is no confirmation that it will be used. The installation cost might also consider being a huge burden for the domestic authority in terms of other commitments of housing. The consulted research on this paper showed that the measures of residential security like window guards, locks, and alarm systems could minimize the risk of burglary at residential premises victimisation (Budd, 2009; and Tseloni, Farrell, Thompson, Evans \& Tilley, 2017). On the other hand, the critics of this idea claim that strategies of target hardening might result in mental ramparts of residents behind their physical blockades that lead to the withdrawal of residents from maintaining and monitoring their neighbourhood or residence (Cozens, Saville \& Hillier, 2005).

\section{Theme 4: Disposing of the Loot}

Good market prices of the stolen items, favourable seasonal conditions and lack of policing strategy are some of the contributing factors to this crime. Criminals work on a risk versus mentality of reward. The risks are minimal, further encouraging potential offenders to

Table 6: Verbatim Expressions on Disposing of the Loot

\begin{tabular}{|c|c|}
\hline Participant 2: & $\begin{array}{c}\text { "There is an open market where most of the stolen items are sold and other items are moved to other towns after } \\
\text { been bought by the illegal buyer" }\end{array}$ \\
\hline Participant 24: & $\begin{array}{c}\text { "The stolen goods market prices, favourable seasonal conditions and increased migration of foreigners are } \\
\text { contributing factors to the stock theft." }\end{array}$ \\
\hline Participant 30: & "The stolen goods during this crime are ready for the local market" \\
\hline Participant 22: & "The stolen goods sold based on the market value, they are sold lower than the market value" \\
\hline Participant 25: & "The local market demands is a key ingredient contributing to this crime" \\
\hline Participant 27: & $\begin{array}{c}\text { "The value of stolen goods is not considered by the relevant stakeholders and the CJS is ineffective, the recovery } \\
\text { chances are very slim" }\end{array}$ \\
\hline Participant 24: & "The selling of the stolen items results in making more money quickly and chances of being caught are very low" \\
\hline
\end{tabular}

Source: Researchers emphasis (2019-2020). 
believe that the chances of getting caught are higher than the reward. This paper revealed that the current reward, or price of a commodity, is recorded to be at a high level. The following emerged from the selected participants regarding this theme:

This is not new, as it always remains the ultimate to burglars to realise the absolute goal they have to convert stolen goods into cash. In support of this assertion, Walsh and Hemmens (2011) postulate that burglars turn to a variety of sources to dispose of the loot, with fences being the preferred method. A fence is a person who regularly buys a stolen property and who often has a legitimate business to cover his activities. Fences are thus valued by burglars because it is the faster way to get rid of 'hot' property, and they are trusted to be discreet. It is noted that burglars without connections to a professional fence turn to pawnbrokers, drug-dealers because it can entail a 'drug-for-merchandise.' Others are said to sell to relatives, friends, and acquaintances because few people can resist buying merchandise even at below 'fire-sale' price.

\section{CONCLUSION AND RECOMMENDATIONS}

It is concluded this paper to probably make a significant contribution to the human knowledge body and in some small way that help to make the world a good place to live. In understanding the nature and extent of the burglary at residential premises in the Namakgale policing area, the following can be presented:

\section{Location of Burglary}

This crime happens in different locations, there is not a targeted area. When it happens in Namakgale Zone A, few houses are found burgled with the same modus operandi for that day. You find electronic items stolen. The following day, it will be happening in Namakgale Zone B and few houses around have been affected as the burglars move from one location to another.

\section{Date of Occurrence}

This crime happens mostly during month ends or [any] paydays as people will be buying property. And usually in rainy and windy days as there is a lot of noise during the night and people will be asleep and would not know whether is the sound of wind or is burglary taking place.

\section{Time of Occurrence}

In most cases; the burglary at residential premises happens during the night when people are sleep. It also happens during the day when people are at work and school. This crime happens during the day at abandoned houses when there is no sign of a person at home. This confirms that the criminals of this crime are very opportunistic.

\section{How Entry was Made}

Burglars break open the back door where there are no lots of movements. When Shops are targeted, burglars are tightened and strong, burglars cut open the Zinc on the roof to gain entry. At school where there is a strong room build of brick, the burglars dig the wall with a shovel or other similar tools to break the wall to gain an entry. Sometimes, burglars do not even enter the house because the items they wish to steal are already outside.

\section{Types of Properties Taken}

Burglars target clothes. They predominantly move around the area with a school bag or something similar during the day taking clothes from the washing line; stealing from few houses before they leave. Commonly, burglars usually target electric appliances. They sometimes do not have an idea of what to steal and take anything they find, which is rare.

\section{Property Identification}

It is very rare to recover the stolen property. The recovered ones are identified using a serial number or trademark. These items are either homemade or bought from the retailer shops. It is not simple to remove a trademark especial when you do not know where it is placed.

\section{Value of Items Stolen in Terms of Rands}

There was an incident in the Namakgale policing area, where the flat-screen TV, cellphone and laptop worth's approximately R15 000-R30 000 were stolen.

\section{Occupancy Status}

Mostly, this crime happens in owned houses than rentals where you will find many tenants sharing a building.

For recommendations; this paper aimed to improve and suggest approaches to improve the cooperation 
and relationship between the SAPS and other government departments. The improvement and suggested approaches aim to address the socioeconomic factors (The intervention of CPF, local community leaders, faith-based organisations, steering committees, local SAPS and municipality and other relevant stakeholders, among others to positively respond to this crime). This paper was also concerned with educating the community on how to prevent them to become victims of burglary at residential premises. And also to educate them not to take law into their own hands when the SAPS do not respond on time when they report an incident. Thus, understanding the respective behaviour of potential criminals of this crime and why certain individuals obey laws about this crime can help in explaining some reasons for its commission. Thus, there have been several theorists who have attempted to explain specifically why people commit this crime. In criminology and policing fields as in virtually all the social sciences), theories compete with one another for acceptance, with none of them adequately satisfying either practitioners or scholars.

Therefore; to effectively address the nature and extent of the burglary at a residential area in the Namakgale policing area, the first responder to the crime scene, SAPS members of uniform must be well trained to attend the crime to avoid contaminating the crime scene. The investigating officers need more training to take the exhibit from the crime scene. Waiting for the LCRC delays the success of the investigation. The LCRC personnel sometimes take too long to arrive at the crime scene because the area is too big and some exhibits are destroyed.

The local SAPS through the CJS should offer counselling to victims of the burglary at residential premises. They need emotional and psychological support from the community and the CJS so they can deal with anxiousness, anger and frustration over their private space being violated and maintain stability in the communities. The local SAPS and community members need to work together in preventing burglary at residential premises.

When these two groups work together they can identify potential offenders and also report those who sell properties around, which might be stolen. This allows the community to work together and there is trust between community members and the SAPS. The community must work with the police to fight against burglary, by reporting the known suspect to the police. The police must be transparent to gain trust from the community. Every member of the community must be responsible for preventing burglary at residential premises by avoiding buying stolen property as this encourages the burglars to burgle.

The community members must be encouraged by the police to participate in community policing forums to increase the number. A member of the community must be encouraged to know the people around their area know their neighbours and have the interest to make a follow up in case they see a stranger within the area. Whenever they see a stranger, they must try to find out what they are doing in their area.

\section{REFERENCES}

Africa Check [Online]. 2020. Factsheet: South Africa's crime statistics for 2019/20. Available from: https://africacheck.org/ factsheets/factsheet-south-africas-crime-statistics-for-201920/ [Accessed: 2020/08/20].

Africa Check [Online]. 2019. Factsheet: South Africa's crime statistics for 2018/19. Available from: -africas-crime-statistics-for-201819/ [Accessed: 2019/10/02]

Aantjes, F. 2012. Residential burglaries A comparison between selfreport studies of burglars and observational data from Enschede. Available from: https://essay.utwente.nl/61668/1/ MSc_F_Aant ... [Accessed: 2019/06/14].

Andresen, MA. 2014.Environmental Criminology: Evolution, theory, and practice. London and New York: Routledge.

Beirne, P \& Messerschmidt, J. 1995. Criminology. Simon \& Schuster: New York.

Budd, T. 2009. Burglary of domestic dwellings: Findings from the British Crime Survey. Available from: https://popcenter.asu. edu/sites/default/files/tools/ ... [Accessed: 2021/04/12].

Cornish, DB \& Clarke, RV. 2008. The rational choice perspective In Environmental criminology and crime analysis. Edited by Wortley, R. \& Mazerolle, L. Pp. 21-47. Willan Publishing: United States of America.

Coupe, T \& Griffiths, M. 1998. Police investigations into residential burglary. The British Criminology Conferences: Selected Proceedings, Volume 1: Emerging Themes in Criminology. 1.

Cozens, P., Saville, G \& Hillier, D. 2005. Crime Prevention through Environmental Design (CPTED): A review and modern bibliography. Property Management, 23(5):328-356. https://doi.org/10.1108/02637470510631483

Dinisman, T \& Moroz, A. 2017. Understanding victims of crime: The impact of the crime and support needs. Available from: https://www.victimsupport.org.uk/site $\quad$... [Accessed: 2020/07/17].

Felson, M \& Clarke, RV. 1998. Opportunity makes the thief: Practical theory for crime prevention (Police Research Series Paper 98). Home Office, Research, Development and Statistics Directorate, Policing and Reducing Crime Unit: London.

Fischer, RJ., Halibozek, EP \& Walters, DC. 2019. Chapter 15: Retail security In: Introduction to Security. 10th Edition. ScienceDirect: United Kingdom, Pp. 363-395. https://doi.org/10.1016/B978-0-12-805310-2.00015-9

Govender, D. 2018. Contact and property related crimes in South Africa: Need for strategies and democratic policing. International Journal of Criminal Justice Sciences, Vol 13 Issue 1, 55-67.

Institute of Security Studies. 2018. Factsheet - South African Crime Statistics - Definitions. Available from: https://issafrica.s3. amazonaws.com/site/uploads ... [Accessed: 2020/07/17]. 
Lushbuugh, C. A \& Weston, P. B. 2009. Criminal investigation: basic perspective. $11^{\text {th }}$ Ed. Library of Congress: United States.

Maluleke, W. 2014. Perspectives on stock theft prevention in the Giyani policing area of Limpopo Province. Unpublished Magister Technologiae Dissertation. Tshwane University of Technology: Soshanguve South.

Maluleke, W. 2020. The African scare of Fall Armwormy: Are South African farmers' immune? International Journal of Social Sciences and Humanity Studies, 12(1), 1309-8063.

Maluleke, W. 2016. The use of Deoxyribonucleic Acid in combating stock theft in South Africa. Unpublished Doctor Technologiae Thesis. Tshwane University of Technology: Soshanguve South.

Maluleke, R. 2018. Victims of crime survey 2017/2018: Statistics South Africa. Available from: http://www.statssa.gov.za/ publications/P0341/ ... [Accessed: 15/02/2019].

Minnaar, A. 2004. Crime prevention, partnership policing and growth of private security: The South African experience. Acta Criminologica, 16(3), 107-123.

Mokwena, RJ, Maluleke, W. 2020. South African rural communities and the land restitution process: The application of criminological and legal theories in identifying obstacles to rightful allocations of land. Gender \& Behaviour Journal, 18(3), $16145-16156$.

Mokwena, RJ.,Motsepe, LL., Maluleke, W., \& Shandu, SN. 2020. A study of land restitution to rural communities in South Africa: An analysis of traditional leaders perceptives. Gender \& Behaviour Journal, (18(3), 16132-16144.

Nunlall, R., Maluleke, W., Breetzke, GD. 2020. Crime mapping In: A Southern African Perspective on Fundamental Criminology. Edited by Bezuidenhout, C. Pearson South Africa (Pty) Ltd: Cape Town [Chapter 14, 542- 571].

Sonne, J. W. 2006. Criminal investigation for the professional investigator. Library of Congress: United States.

South African Police Service. 2014. Crime research and statistics South African Police Service: For April to March 2003/2004 2013-2014 [Online]. Available from: http://www.saps.gov.za/ statistics/reports/crime ... [Accessed: 2017/04/06].
South African Police Service Crime Statistics. 2012-2020. Burglary at residential premises: Namakgale. Available from: http://www.crimestatssa.com/provin $\quad \ldots \quad$ [Accessed: 2020/01/10].

Tseloni, A., Farrell, G., Thompson, R., Evans, E \& Tilley, N. 2017. Domestic burglary drops and the security hypothesis. Crime Science, 6:3, 1-16. https://doi.org/10.1186/s40163-017-0064-2

Van Zyl, GS. 2006. Residential burglary in South Africa: A geographical perspective. Unpublished Doctoral Thesis, Faculty of Humanities, Department of Geography, Geoinformatics, Meteorology. University of Pretoria: Hartfield.

Victims of Crime Survey [Online]. 2018/19.Statistical release P0341 Victims of Crime Governance, Public Safety and Justice Survey. Statistics South Africa: Pretoria.

Walsh, A\& Hemmens, C. 2011. Introduction to criminology: A text/reader. 2nd Edition. Thousand Oaks, CA: Sage.

Welsh, BC \& Farrington, DP. 2012. Crime prevention and public policy In: The Oxford Handbook of crime prevention. Edited by Farrington, DP \& Welsh, BC. https://doi.org/10.1093/oxfordhb/9780195398823.001.0001

Wollinger G, Dreißigacker, A \& Baier, D. 2017. Residential burglary: Main results of a study in Germany. Sociology and Criminology-Open Access, 5(1).

Wright, RA \& Miller, M.J. 2005.Encyclopedia of criminology. Volume 1: A-G. Routledge: New York.

Zinn, R. 2017. Burglary - The biggest crime. May 8, Kempton Express [Online]. Available from: https://kemptonexpress. co.za/268518/burglary-the-biggest-crime-hitting [Accessed: 2020/09/15].

Zinn, R. 2010. Home Invasion: Robbers disclose what you should know. Tafelberg: Cape Town.

Zinn, R. 2018. What burglars do not want you to know? Available from: https://lowvelder.co.za/346784/what-burglars-dont-want ...[Accessed: 2020/09/15]

Received on 12-07-2021

Accepted on 06-09-2021

Published on 29-09-2021

https://doi.org/10.6000/1929-4409.2021.10.157

(C) 2021 Mundlovu et al.; Licensee Lifescience Global.

This is an open access article licensed under the terms of the Creative Commons Attribution License (http://creativecommons.org/licenses/by/4.0/) which permits unrestricted use, distribution and reproduction in any medium, provided the work is properly cited. 